\title{
Emerging Vocabulary: The Influence of English on Medical Spanish
}

\author{
Alicia Ricart Vayá and Miguel Ángel Candel Mora \\ Polytechnic University of Valencia \\ alriva@idm.upv.es
}

\begin{abstract}
This paper discusses the influence of the use of English as a lingua franca in the field of academic research in medicine and its effects on the Spanish medical language, as evidenced after an in-depth revision of the existing literature. The study has been based on the analysis of a medical corpus made up of 311 Conclusion sections of Spanish articles, which correspond to the specialties of Cardiology, Paediatrics and Psychology.

Upon justifying the decision of using the English language as essential for academic life and international communication, the discussion focuses on the impact of the specialized literature on professionals whose native language is not English and the inclusion of new vocabulary sometimes justified as the result of a need on the part of scientists to explain new concepts.

The massive incorporation of vocabulary has led researchers to deal with the different ways in which neologisms are introduced in the Spanish medical language analyzing the corresponding results, which include: words from other languages which are slightly modified; words from other languages added with or without morphological adaptation; addition of suffixes or prefixes; the use of "false friends" and the use of certain words not registered in the dictionary.
\end{abstract}

\section{English as a Lingua Franca}

In recent years the fast development in technology and commerce has led researchers to put their experiences into words. In this process, English has become the lingua franca of scientific and commercial sectors (Alcaraz 2000:14). It is obvious that English is vital for 
academic life and international communication and thus anyone who intends to succeed in the scientific community has to write necessarily in English.

Linguists agree that English is the most widely used foreign language in Europe (Petzold and Berns 2000:113-124; Berg et al., 2001:305-319). For Crystal (1997:3-54) in order to reach the status of global language, a language needs to be taken up by other countries. This happens for instance in some countries that make another language the official language and use it for the media, educational system, the government, etc. (e.g. India). Their inhabitants are bound to command this official language, called foreign language, as early as possible, because it is a complement to their native language. This is the status that English has in over seventy countries, such as Ghana, Nigeria, India, Singapore, etc. The second way in which a language is taken up is by making it a priority in the country's foreign-language teaching, despite not having an official status. Kachru (2001) illustrates the spread of English around the world and its acquisition and use by means of 3 concentric circles:

a) the inner circle, containing between 320 and 380 million people, represents those countries in which English is the primary language. People in this circle speak Standard British or American English (e.g. the USA, the UK, Ireland, Canada, Australia and New Zealand),

b) the outer or extended circle, with 150-300 million people, represents those countries where English was spread in a non-native setting and the language has become part of a country's main institutions, playing therefore a relevant "foreign language" role in a multilingual setting (e.g. Singapore, India, etc),

c) and finally the expanding circle, represented by 100-1,000 million people, which includes those countries which consider English an international language but have no history of colonization by those in the inner circle. The language does not have an administrative status either (e.g. China, Japan, Greece, etc). In this case English is called a foreign language. English has this status in over 100 countries, such as China, Russia, Germany, Spain, etc.

It is therefore not surprising that English is currently the most widely taught, read and spoken language (Kachru and Nelson 2001). According to a study carried out by Aragoneses et al. in 2002, (Ruiz 2003:14) 90\% of the students in all E.U. countries study English, whereas only $34 \%$ study French, 15\% German and 10\% Spanish. As far as the percentage of language speakers in the E.U. is concerned, $47 \%$ of all speakers have English as either their mothertongue (16\%) or as a foreign or second language (further referred to as L2) (31\%).

Increasingly, the status of English as an international language (Bhatia 1997:313-319) or a global language (Crystal 1997) has led to the importance of its teaching and learning not only in Europe but all over the world. Alcaraz (2000:14) adds that English as a foreign Language is one of the most important components of the syllabus in primary and secondary schools all over the world.

Graddol (1997) suggests that in the near future the number of speakers of English as a foreign language will be greater than that of those who speak it as their L1 and as their L2. According to Crystal (1997:130), despite the number of L1 speakers being greater at the moment, if current population and learning trends continue, L2 speakers will overcome those with English as an L1 in 10 years time because the countries of L2 speakers have a much greater growth rate. These expectations lead us to the idea that the only possible concept of 
ownership of the language in some years will be a global one.

Some authors (Navarro, 2001; Fortanet, 2002; Crystal, 1997) suggest acting against this international scene of predominance of a language and consequent discrimination of others because otherwise they consider to be accepting a secondary position in the world's science. Similarly, Fortanet (2002:20) is against consulting only Anglo-American bibliography and advocates checking first national bibliography and then European or from any other country in the world. Crystal (1997:12-13) also underlines the fears for the danger of a possible disappearance of minority languages as a consequence of a presence of a global language that could make people lazy about learning other languages, since the existence of a global language would make all other unnecessary. Actually, the process of dominance and loss of languages has been known to take place throughout history, but for Crystal this occurs independently of the emergence of a global language (1997:17).

In contrast to those who oppose a global language, other authors do not object to the idea of a global language and suggest that it would result in unity and peace as linguistic misunderstanding would disappear. However, having a look at history, it seems clear that a single language does not necessarily mean social harmony or mutual understanding. Evidence is represented by the Spanish or the American Civil War, The Vietnam War, etc. House (1999:73-89) also underlines the advantages of English as a lingua franca in Europe, for instance, the fact that it gives rise to a functional flexibility by its wide international extension and thus becomes a very useful tool of communication for different regions and identities that can have English as a common means of communication.

\section{Medical language and its influence on Spanish}

According to Ballesteros (2003:2), Medical language stems from the times of ancient Greece in IV and V b.C and has therefore Greek roots. Despite the fact that the Arabs stayed in Spain for 8 centuries, their influence on the Spanish vocabulary in general is very low, and it is even lower in the field of medicine. Other languages spoken in the Iberian Peninsula (e.g. Portuguese and Catalan) or close to it, like Italian, have influenced the general Spanish language, but not the medical language.

In general, scientific language has absorbed through time many terms from foreign languages that were dominant in a certain period of time because of cultural and/or economic reasons. As pointed by Ballesteros $(2003: 2)$, in the $18^{\text {th }}$ and $19^{\text {th }}$ century, Germany was the most outstanding country regarding the discipline of medicine. However, German researchers and other researchers from central Europe had a tendency to create neologisms based on Latin, which was the language studied at university by that time. Consequently, the Germanic influence is not relevant in the medical language. By contrast, French has had an influence on the Spanish language throughout history, and especially after Philip the $5^{\text {th }}$ 's reign and up to the $20^{\text {th }}$ century. The influence of French neologisms on Spanish medical language is considerable. For example, the suffix -age was adopted in the Spanish language with a slight change in spelling, i.e. the replacement of the letter "g" with the letter "j", namely "-age" became - aje and words such as drenaje appeared as a result of the influence of French in the 
Spanish language.

English had very little influence on Spanish up to the middle of the $20^{\text {th }}$ century. However, the Second World War and the consequent economical and scientific leadership of the USA brought anglicisms not only to the Spanish language, but to all languages in the world. Ballesteros (2003:3) notes the incomparable influence of anglicisms.

Scientific hegemony in science was the main via to the spread of anglicisms, in fact, in the discipline of medicine one fourth of Spanish medical books have been translated from the English language, and over $80 \%$ of the bibliographical references in Spanish medical books come from journals that have been written English and stem from either Anglo-Saxon countries or non Anglo-Saxon countries.

\subsection{New emerging vocabulary.}

In the field of medicine constant advances have led medical doctors to create new vocabulary to refer to the latest concepts and discoveries. Ballesteros (2003) highlights the need of modern languages to be able to adapt to the mentioned medical breakthrough.

The arrival of foreign words to the Spanish language was started by researchers as a consequence of scientific progress and for cultural and social reasons. However, the inclusion of anglicisms after the Second World War was originated through the media by people who did not have much linguistic knowledge of the English language and used foreign words not as a consequence of a need to refer to something new, but rather, many times they resorted to neologisms with the purpose of making information sound more modern.

The use of anglicisms without knowing the style guidelines of the English language is criticized by Mayor (2006:133), who underlines the importance of knowing style norms especially to communicate in the English and Spanish medical context without language interferences.

Apart from Mayor, several authors claim that the inclusion of new vocabulary is sometimes not the result of a need on the part of scientists to explain new concepts but rather of other factors such as ignorance, idleness and pedantry (Iscla and Aleixandre 2003). According to Lázaro Carreter (1997) "algunos extranjerismos obedecen más a la necedad que a la necesidad" (Ballesteros, 2003).

According to Ballesteros (2003:2), the inclusion of new vocabulary is many times against the most important characteristics of medical language, namely, clarity and conciseness. Language needs to be precise and simple since it aims at transmitting the message without difficulties.

The only aspects that justify the incorporation of a new word in the vocabulary are the following (Ballesteros 2003:3-4):

The only reason for the incorporation of a neologism is the inexistence of a term that brings the researcher to the need to create a new one. As an example he criticizes the incorporation of posicionar because of the existence of the equivalent Spanish verbs situar and colocar. Another author that shares Fernández's opinion is Navarro (1992:588) that defines the neologism posicionar as "horrible neologismo calcado del inglés" and suggests more alternatives to the ones proposed by Ballesteros like tomar posición, emplazar. 
b) The term has to be adapted to Spanish linguistic norms. Fernández (2004:34-36) refers to the problem that there are very few norms to establish a criterion in terms of incorporation of neologisms regarding orthography (e.g. Japón, Paris, both with an accent but Washington). Fernández (2004:36) also underlines the additional problem that the Real Academia de la Lengua Española (further referred to as Real Academia) has not established clear criteria in relation to the inclusion and rejection of words. Navarro (1992:575) refers to the occasionally difficult eradication of anglicisms once they are widely used in medical texts.

\section{Different methods to increase medical vocabulary}

The impoverishment denounced by several authors (Iscla; Aleixandre, 2003) of the Spanish medical language caused by different factors is also reflected in the Spanish corpus of this research work. From the many areas covered by different linguistic experts in relation with the influence of neologisms on the Spanish medical language and regarding the influence of English on Spanish and the consequent translation problems in the last years, most aspects have been registered in the present study. Although most areas were analyzed at the semantic level, special attention has been devoted to derivation and loanwords.

The massive incorporation of vocabulary not based on any of the above reasons has led researchers to deal with the different ways in which neologisms are introduced in the Spanish medical language analyzing plausible resulting problems (Martínez, 2006; Aleixandre 2003, among others).

In the field of semantics, Martínez (2006:84-90) and other authors (Ballesteros 2003:4) provide us with different lexico-semantic options in which the Spanish language is enlarged by emerging vocabulary:

\subsection{Words from other languages}

Words from other languages are slightly modified in terms of spelling and are adapted and accepted by the Real Academia to the Spanish language (e.g. estrés, escáner, chequeo, estándar, etc). Some instances that have been identified in our corpus are the terms estrés, estándar, láser, déficit, items and hobbies.

In other instances these words from other languages are added to the language with or without morphological adaptation. In this case, some examples of words with no morphological adaptation, are: shock and test. This phenomenon is the most frequent in the last years (Navarro 1992:575) and it is criticized because the use of these words is not due to the need to express something new, rather, these words have an equivalent in Spanish, which should be used instead (e.g. second-look instead of revisión, shunt instead of derivación, cortocircuito, comunicación or anastomosis (Navarro 1992:579), randomizado instead of aleatorizado, by-pass instead of derivación, puente or anastomosis, adherencial instead of adherente, plug instead of tapón, mandatorio instead of obligatorio, screening instead of cribado and bleb instead of ampolla or bulla, etc.). Iscla and Aleixandre (2003:4) provide us with other examples such as the use of nodal instead of ganglionar. 
The majority of words identified in medical Spanish coming from other modern languages are anglicisms, followed by foreign words from French, Italian, Arab and German in this order (Fernández 2004:32). The high rate of anglicisms and false friends in Spanish medical texts is to a great extent due to the fact that most Spanish publications are based on English bibliography (Navarro 1994:142). In 1992, Navarro (1992:589) congratulates the DRAE (Diccionario de la Real Academia Española) for their task of incorporating neologisms and well as eradicating others (e.g. morbididad and only morbilidad is accepted for euphonic reasons). However, he differentiates between anglicisms that are necessary and desirable (Navarro 1992:587) such as dopar, dopado and dopaje and those that are not. In the case of dopar he considers it necessary because it conveys an additional meaning to that of the Spanish verb drogar/se. The English verb dope implies the consumption of drugs with the purpose of improving stamina. As pointed by Rodriguez (1992:178) it is used in relation to competitions, contests. On the other hand, he criticizes the acceptance of some anglicisms by the DRAE like discapacitado and discapacidad, which the DRAE recognises as calques of the English term disabled. Navarro refers to them as blatant anglicisms (descarados anglicismos) (1993:587) that have the intention of replacing minusvalía and minusválido. Among other anglicisms accepted by the DRAE that Navarro considers unacceptable are rango, relax, test, etc.). Navarro's point of view is shared by Fernández (2004:37) who expresses his concern about the possibility of neglecting the own words as a consequence of the use of unnecessary anglicisms.

Navarro (1994:504) underlines the importance of adapting anglicisms to our language since the future of most languages relies on their capacity to coin new technical and scientific terms. As a consequence, he denounces those who consider the language a mere mean of communication in the field of science and do not care about the intrusion of unnecessary anglicisms and disregard the cultural value of languages.

Ballesteros (2003:4) affirms that the Spanish language cannot easily produce short terms to replace Anglicims, and this accounts for the phenomenon described in the above paragraph, i.e. the increasing adoption of anglicisms. As an example, he compares the term stent with prótesis endovascular. Fernández (2004:21-22) also supports this idea as he refers to Cabré who explains the preference to use Alzheimer rather than patología de carácter neurodegenerativo que en el lenguaje médico se caracteriza como demencia. This deficiency of the Spanish language to create short Spanish equivalences is also reflected in the fact that sometimes researchers end up resorting to Greek terms instead of the Spanish ones preferring a shorter terminology. For instance, the term Hairy cell leukaemia translated for leucemia de células peludas would reasonably be substituted by tricoleucemia. This word contains the prefix trico- from the Greek noun trikos meaning hair. Admittedly, tricolucemia is more euphonic than leucemia de células peludas. Navarro (1994:509) advocates for tricolucemia and emphasizes the need for a terminological uniformity. Ballesteros (2003:4) states that euphony is also a reason that accounts for the use of one term rather than another in the field of medicine. To illustrate this with an example, kill cell corresponding to célula asesina in Spanish was substituted by célula citocida with its root in the Latin verb occido meaning to kill. Navarro (1994:510) prefers célula citolítica to célula citocida.

The incorporation of words from other languages without morphological adaptation 
denounced by several Spanish linguists (Martínez, 2006; Aleixandre, 2003), especially when a Spanish equivalent exists, takes place in our Spanish corpus. For instance, Navarro (1992:577) states that feed-back is not admitted, it is what Haugen (1950) calls a substitution. In fact, Navarro adds that it can be replaced by retroalimentación in some cases as in the example of the corpus "Lo más destacable es el hecho de que esta evolución positiva que se da en la capacidad de interacción de los pacientes se relacione estrechamente con el avance que observamos en los terapeutas, que hicieron servir como feed-back el análisis de las sesiones anteriores." Rodríguez (1997:207) adds other possible translations for the word like retroacción and retroalimentación. Some other examples of English words in the corpus are: Problem solving, Life events, Coping used in estrategias de coping, test-retest, etc. (e.g. "Los especialistas reafirman la importancia de estos life events que ocupan uno de los primeros lugares en el rango de impacto de riesgo" or "Es necesario que en futuros trabajos se estudien la factibilidad, la fiabilidad en términos de consistencia interna y estabilidad test-retest, y la validez").

The noun screening is present in the corpus especially in combination with the noun instrumento, when the equivalent cribado should be used instead (e.g. los síntomas que en concreto se seleccionen para confeccionar un instrumento de screening del TS no parecen ser relevantes para que el test resulte válido,...). Other suggestions to translate screening into Spanish according to Navarro (1994:147) are selección sistemática or detección sistemática. Sometimes, the neologism in the corpus is a compound made of an existing term and an English one, for instance: inmortales like (e. g. “...con el consecuente bloqueo de la apoptosis, dejando en funcionamiento clones celulares inmortales-like [en queratinocitos], proceso que...").

Considering that one of the disciplines in the corpus is cardiology, it is not surprising that the anglicism "stent" appears repeatedly in the corpus (e.g. "Con el tipo de stent utilizado ha sido posible intentar el implante directo en todos los casos..."). According to Navarro (1994:513), the most suitable translation for this substitution is endoprótesis vascular and prefers other possibilities such as resorte intravascular, tutor intravascular or tubo expansible rather than the anglicisms stent and estén.

\subsection{Derivation}

Existing words, mainly nouns, are turned after a process of derivation into a new term especially by the addition of a certain suffix or prefix. These group of words are new formations or hybrids in Hauguen's terminology. This addition implies a change in meaning and sometimes it also changes the grammatical category of the word (e.g. antibioticoterapia, meaning the treatment of a patient with antibiotics, or the verb protetizar, derived from the noun prótesis, meaning to implant a prosthesis). Other typical examples have taken place by the addition of the suffix -al turning nouns into adjectives like muestral, situacional, poblacional. This new terminology is not accepted at the beginning by the Real Academia. However, when the use becomes evident and wide, many of these terms are finally included in the Diccionario de la Real Academia Española. Martinez (2006:84) recognizes the advantage of this mechanism that favors the fluency of the text avoiding verbal periphrases, 
but he underlines the risk of overusing them. In fact, sometimes words suffer this kind of transformation, when it is absolutely unnecessary. The addition or change of the new suffix does not contribute to expressing a different nuisance in terms of meaning. (e.g. objetivizar instead of objetivar or lesional instead of lesivo).

The flexible structure of the Spanish language is reflected in the many words that the Real Academia initially rejected but has accepted with time. Some of them are: enfatizar, concretizar (as a synonym of concretar), chance (as a synonym of oportunidad), analitica (for análisis clínico), inusual, injuria etc. The latter terms show a clear influence of the English language terms unusual and injury. This flexible feature of the language is underlined by Ballesteros (2003:7) when he makes reference to Fray Luis de León's sentence “nuestra lengua es de cera para los que saben tratarla".

Other terms which could also be considered unnecessary in terms of semantics are the many Latin terms used that have a Spanish equivalent. Their use in medicine is very spread and accepted, but Martinez insists on not overusing them and provides us with a list of the most used in the discipline of medicine: a priori, a posteriori, ad hoc, ex profeso, in situ, sine qua non, versus, etc.

During the analysis of the Spanish corpus, a list was created containing words that are not registered in the Spanish dictionaries at the present time. The dictionaries consulted were the D.R.A.E. (2001), Diccionario de la Real Academia Española, and Diccionario abreviado del español actual (2000). The authors of the journal articles produced a significant number of previously unattested words using different strategies. The most common method to create new words used in the Spanish medical corpus analyzed is the strategy of derivation by means of the addition of different suffixes and prefixes to existing words.

\subsubsection{Use of existing prefixes to form neologisms}

According to Gómez (2002:19), prefixes do not change the grammatical category of words but their function is precisely to give a new meaning to the word they are added to. In the corpus the following prefixes were identified in order to create new words within the same category.

The prefix in-, usually conveys a negative meaning to the adjective with which it is combined and turns it to mean the opposite. According to Gómez (2002:20) the prefix in means no. In the DRAE (2001) the same meaning for the suffix is given (e.g. negation or deprivation). An instance is the adjective inalcanzable that means something cannot be reached. However, in the DRAE an additional meaning for the suffix -in is inside (e.g. incluir). In the corpus, this prefix is applied with the first meaning indicated, negation, to adjectives that do not admit it such as inespecifico or inefectiva. It is difficult to know whether inespecifico is simply a new word coined by the author or whether its origin is related to the English unspecified.

Another prefix used to form adjectives in the corpus is multi-. It is used in Spanish to mean many (DRAE, 2001) and it is applied to words like factorial giving rise to the up to now unattested adjective multifactorial.

The prefix hetero- used to denote different, unequal, another (e.g. DRAE, 2001) like in 
heterosexual is applied to the participle aplicada giving as a result heteroaplicada. And finally, the prefix uni- meaning one (e.g. unidireccional) generates terms like unimodal.

Many prefixes can be used to create new verbs and nouns. For instance, the prefix sobre-, which in Spanish conveys intensification of the noun it precedes (e.g. sobrealimentación). Other meanings registered in the DRAE (2001) are repetition (e.g. sobrecenar), sudden action (e.g. sobrecoger) and addition or superposition (e.g. sobrecalzada). For example, the prefix can be applied to the adjective valorado but also to the verb valorar resulting in the adjective sobrevalorado and the verb sobrevalorar, respectively. The application of this prefix is with the meaning of intensification is applied to other nouns creating neologisms such as: sobrepuntuación and sobrerepresentación.

Similarly, the prefix infra-can be considered an antonym of sobre- in the sense that according to the DRAE (2001) the meaning it conveys to the words it is added to is inferior, under (e.g. infrahumano). For instance in infravalorar which means undervalue or underestimate. In the corpus, it is applied to the noun tratamiento creating the new term infratratamiento.

The prefix sub-, which is similar in meaning to infra-also conveys the idea of under (DRAE, 2001) as in subsuelo or subestimar. The DRAE (2001) registers other occasional meanings for this prefix such as inferiority, diminish and decrease. In the corpus it generated previously unrecorded terms such as subtest and subescala where the suffix' meaning is under.

The prefix co- is registered in the DRAE (2001) with the meaning of cooperation (e.g. confluir). It is applied to the neologism responsabilización, giving rise to the previously unattested noun corresponsabilización.

According to the DRAE (2001), the prefix inter-conveys the meanings: between or among and in the middle (e.g. intercostal). In the corpus it generates nouns like intersujetos.

The prefix hiper- gives an intensifying meaning to the word it is added to (Gómez, 2002:20); thus, it provides the word with a meaning of superiority or excess as in hypertension (DRAE, 2001). This prefix gives rise to nouns like hipervigilante.

The prefix intra-, meaning inside-(DRAE, 2001) as in intravenoso, is used together with the noun grupo and results in the noun intragrupo.

The prefix auto- meaning own (DRAE, 2001), e.g. autobiografia, is added to words that have different morphological categories such as the noun autoinforme, the verb autodirigir or the adjective autoseleccionados, forming words that are not registered in the dictionary.

The prefix $r e$-can provide the word to which it is added with different meanings according to Gómez (2002:19) and to the DRAE (2001). It can be used to intensify (e.g. relimpio) but it can also mean backwards (e.g. recular, refluir) and it is frequently used to indicate repetition (e.g. releer). This latter meaning is the one registered in the medical corpus and it is added mainly to nouns but also to adjectives, creating the neologisms reintroducción, rediagnosticados, redefinición or reactualización.

Although normally prefixes do not change the grammatical category of the word, Gómez (2002:19) indicates that some modern prefixes such as post-but also multi- and anti-do turn nouns into adjectives.

The prefixes pre-and post-, indicating normally before/earlier and after/later, respectively 
(DRAE, 2001). They are added to words with or without a hyphen creating the neologisms pre-tratamiento, pre-adulto, presuicida, pos-tratamiento, postinfarto, postalta. The original nouns tratamiento, adulto, suicida, infarto and alta in the examples stated above turn into adjectives in some instances of the corpus (e.g. angina postinfarto or revascularización postalta).

\subsubsection{Use of existing suffixes to form neologisms}

Regarding the use of suffixes to create new words that are not registered in the dictionary, the neologisms registered in the Spanish corpus are made of the so called obligatorios suffixes (Gómez, 2002:23). These suffixes are added to words changing their grammatical category.

The use of the suffix -able is normally used in Spanish to create a new verbal adjective that indicates that something is possible, namely a passive possibility (DRAE, 2001). For instance, the adjective realizable that means that something can be done. This suffix is applied to other words, creating non-registered adjectives like diferenciable or objetivable.

Another suffix used to create non recorded adjectives is - $a l$, which is normally added to mean group as in instrumental, meaning group of instruments (Gómez, 2002:23). This suffix can also indicate relationship or ownership according to the DRAE, 2001. In the corpus the second meaning of the suffix is the one recognized in the adjective atencional (e.g. "Asimismo, se investigan la integración perceptiva en el tiempo debida a la atención, la evolución diacrónica del sesgo atencional o la naturaleza de la orientación atencional en el tiempo..."). Similarly, in the previously unattested adjective comportamental, the meaning of the suffix implying group is not recognized ("Entonces y tal como señalábamos en la introducción las personas liberales son más erotofílicas y las conservadoras más erotofóbicas, aunque esto no tenga porque ser siempre así, dado que los componentes de las actitudes (cognoscitivo, afectivo y comportamental)..."). Thus, taking the example into account the adjective comportamental seems to be a loan translation of the English term behavioral rather than to only a case of derivation.

The suffix -ador normally refers to someone who carries out an action, i.e. to the "agent" according to the DRAE (2001). For instance, cazador, from the verb cazar, corresponding to hunter and to the verb to hunt in English. It is applied to the verb optimizar in the corpus, originating the adjective optimizador. Other meanings of the suffix registered in the DRAE (2001) are device (e.g. acelerador), place (e.g. comedor), but none of the above meanings of the suffix can be recognized in optimizador, which is additionally not included in the dictionary.

The suffix -ado belongs to the category expressing collectivity or group according to Gomez's classification (2002:23). In the corpus the adjective mistificado seems more a case of what Gómez (2002:21) calls a postativo or apreciativo suffix with no grammatical change of the word, however, no nuance different to the adjective mistico can be appreciated in mistificado (e.g. "En tal priorización de necesidades, no se ha de obviar la raigambre sociocultural del mistificado fenómeno de las drogodependencias, ni los efectos derivados de ..."); thus, it might be a loan translation of the English participle mystified. As for the adjective aleatorizado, the same unjustified use of the suffix takes place; the appearance of 
this adjective in the medical corpus can only be associated with a loan translation of the English word randomized (e.g. "o se trata de un estudio verdaderamente aleatorizado").

The suffix -oide, sometimes also -oides stems from the Greek and it conveys the meaning of en forma de and parecido a meaning similar to (DRAE, 2001), for instance the adjective androide means similar to a man. This suffix is added to the noun cannabis in the corpus originating cannabinoides, which should be understood as similar to cannabis.

The suffix -ista is conferred the meaning of partidario de in the DRAE (2001) meaning supporter or fond of but as pointed by Gómez (2002:24). The neologism registered in the corpus is salubrista, in which the first meaning supporter can be recognized. Thus, salubrista is the adjective referring to someone who is a supporter of health, in Spanish partidario de la salud (e.g. "... en aras de promover actitudes y conductas optimizadoras vinculadas a una política salubrista, reivindicación necesaria a todos los efectos").

The suffix -mente normally turns adjectives into adverbs (DRAE, 2001). Gómez (2002:25) states that the meaning this suffix conveys has to do with modality. In the corpus this meaning of the suffix is recognized when it is added to adjectives that do not admit it such as admitidamente, espuriamente, comprehensivamente or artefactualmente, transculturalmente. The following example illustrates the use of the existing adverb admittedly in English: "Additionally, the number of patients studied was limited and, admittedly, the specific correlations that we have found are only indications" versus the neologism admitidamente in Spanish: "Admitidamente, nuestra muestra es limitada y sesgada, se trata de parejas que fueron derivadas a un centro...".

\subsection{False friends}

The use of false friends, that is, of words that are translated on the grounds of presenting a morphological similitude with a word in the other language. These would be categorised as semantic loans according to Hauguen. The most common false friend is the use of severo instead of grave as a translation of the English term severe. The Spanish adjective severo means strict and not serious as the English adjective severe. The frequent misuse of the noun severo has turned it to be used in the same context as the English severe and consequently it has adopted the English meaning, which does not correspond with its actual meaning. In fact, the first translation registered in the Collins dictionary (1994) for the adjective severe is severo. Another example is the translation of the English tablet for tableta, nodal instead of ganglionar or protrusion instead of saliente or protuberancia (Martínez 2006:85). Another example that is worth mentioning is evidence that should be translated for proof or finding, i.e. prueba or hallazgo but it is by no means evidencia. As pointed by Navarro (2005:345) the word evidencia in Spanish means: "certeza clara, manifiesta y tan perceptible de una cosa, que nadie puede racionalmente dudar de ella", thus, evidencia in Spanish is used to imply that something does not need to be demonstrated because it is clear. The level of certainty of the word evidence in English is much lower, thus it would correspond in Spanish to indicios, signos, datos, pruebas. Therefore, the sentence "There is no evidence that breast implants cause serious disease" would correspond in Spanish to "no hay ningún indicio de que los implantes mamarios provoquen enfermedades graves". 
Regarding false friends in the field of medicine, Navarro (2005) collects many of them in his work Diccionario crítico de dudas inglés-español de medicina (2005). In the introduction the author criticizes the existing medical dictionaries that collect cognates with the same meaning in both languages but do not deal properly with problematic words such as false cognates. Navarro (2005) devotes his dictionary especially to clarify these complex words. For instance, the word "anthrax" does not correspond to the Spanish ántrax but to carbunco, i.e carbuncle. Similarly, the English labor does not correspond to the Spanish labor but it means childbirth, and so on.

Some examples of neologisms that are a probable consequence of the spread of false friends in the Spanish language when carrying out translations are present in the corpus.

For instance tableta is used instead of comprimido based on the English term tablet, which is the abbreviation of compressed tablet (Navarro, 2000:985), (e.g. "Por ejemplo, prescribir la mitad de una tableta de sertralina de $100 \mathrm{mg}$ al día es la mitad de caro que prescribir una tableta de sertralina completa de $50 \mathrm{mg}$ al día"). The noun evidencia is very commonly used with the same meaning as evidence in English, rather than with the Spanish meaning of "certeza clara ... que nadie puede dudar de ella" (see Navarro, 2005 above).

According to the Collins Cobuild English Language Dictionary (1987) evidence is "anything that you see, experience, read, or are told that causes you to believe that something is true or has really happened" (e.g. "Este resultado es consonante con la evidencia obtenida en el ámbito de estudio del estrés familiar que subraya la estrecha relación e interdependencia existente entre el funcionamiento familiar y la presencia de estresores normativos y no normativos..." or "hay que tener en cuenta que los artículos revisados generan poca evidencia científica ya que se tratan..."). It is important to mention that the translation for the noun evidence in the Collins Spanish Dictionary is evidencia, which makes the misuse of the word more understanding.

Navarro (2005:297) provides us with multiple options for the translation of the term dramatic into Spanish depending on the context: impresionante, espectacular, considerable, sensacional, gravísimo, claro, intenso, tajante, sorprendente, imponente, súbito, descomunal, etc. The adjective dramática is present in the corpus and has been probably used instead of considerable, impresionante or espectacular possibly as a semantic loan based on the English adjective dramatic (e.g. "La escasez de donantes pequeños limita de forma dramática la posibilidad de conseguir injertos para candidatos de bajo peso lo cual hace necesario la búsqueda de alternativas quirúrgicas").

The presence of the adjective severo in the corpus seems to be a misuse as a consequence of influence of the English severe often translated as severo rather than as serious, in Spanish serio o grave (e.g. "A pesar de que los TP inicialmente presentan un estado psicopatológico más severo el grado de cambio clínico logrado no diferencia a los dos grupos,...”). Navarro (2000:912) explains that the adjective severo in Spanish means serio or riguroso and that it can only be used to define a person's character. Therefore he distinguishes several possible equivalences to the English adjective severe depending on the context (e.g. grave as in severe situation, intenso or fuerte as in he had severe loss of blood, translated for una fuerte hemorragia, extenso as in severe acne, etc.). Finally he mentions the wide use of the inappropriate adjective severo in Spanish and underlines that linguists tend to stop correcting 
the inappropriate use of the term.

The adverb comprehensivamente is recorded in the corpus. It is modelled on the English adjective comprehensive. Navarro (2000:210) suggest different options for the translation of the adjective comprehensive according to the context: amplio, completo, extenso, general, exhaustivo, etc. In the corpus, the adverbs ampliamente or exhaustivamente should have replaced comprehensivamente (e.g. “...un fenómeno multidimensional que se ha de abordar comprehensivamente").

\subsection{Words not in dictionary}

Sometimes words are given a meaning that has not been registered in the dictionary. The word bulla in Spanish is defined in the dictionary as concurrencia de mucha gente, thus, it is a synonym of the English word crowd; however it is used to refer to ampolla or blister. Another example is adolecer defined in Spanish as something having a defect or vice. However, in the corpus it is used with the meaning of to lack (e.g. "De manera similar a trabajos previos, este estudio adolece de algunas limitaciones metodológicas, que pueden influir en los resultados, como por ejemplo, control de la sintomatología ansiosodepresiva..."). Similarly, obertura refers in Spanish to overture but it is used with the meaning of opening or gap.

\section{Conclusions}

The present research work revises the different areas related to the creation and influence of neologisms in the Spanish language. It can be stated that anglicisms, borrowings and derivation are the main methods for the creation of neologisms in the medical field. Thus, it is loanwords and semantic loans that take mainly place in Spanish medical texts. Despite the critique of different authors, Spanish medical language continues to adapt false friends and anglicisms incessantly. The use of anglicisms has to do on many occasions with the capacity of the English language to condense a great deal of information into a few words.

Additionally, although anglicisms do not always imply shortness, their spread use in English medical texts leads Spanish medical doctors familiar with English medical literature to incorporate them in their Spanish publications.

If linguists do not strive in their task of analyzing and limiting the acceptance of certain foreign terms and structures, Spanish medical language will turn into a hybrid language.

\section{References}

Alcaraz Varó (2000) El inglés profesional y académico. Madrid. Alianza editorial S.A.

Ballesteros Fernández, .A. (2003) El lenguaje de los médicos. El médico interactivo. Diario electrónico de la sanidad. $\mathrm{n}^{\circ} 892-10$.

http://www.medynet.com/elmedico/informes/informe/lenguagjemedico.htm.

Berg, E.C., Hult, F.M. and King, K.A. (2001). Shaping the cimate for language shift? English 
in Sweden's elite domains. World Englishes, 20 (3), 305-319.

Bhatia, V.K (1997). Introduction: Genre analysis and world Englishes. World Englishes, 16 (3), 313-319.

Collins Cobuild English Dictionary. Harper Collins Publishers. London: 1995.

Crystal, D. (1997) English as a Global Language. Cambridge, U K. Cambridge

Fernández, M. (2004) La incorporación de neologismos al español actual. Extranjerismos y nuevas acepciones. Ávila: Universidad Católica de Ávila.

Fortanet Gómez, I. (2002) Cómo escribir un artículo de investigación en inglés. Madrid: Alianza Editorial, S.A.

Gómez Torrego, L. (2002) Gramática didáctica del español. Madrid: Ediciones SM. 18-25.

Graddol, D. (1997a) The future of English? London: The British Council.

Haugen, O.E. 1950. 'The Analysis of Linguistic Borrowing'. Language 26:210-31.

House, J. (1999): "Misunderstanding in intercultural communication: interactions in English as a lingua franca and the myth of mutual intelligibility" in C. Gnutzmann (ed.), 73-89.

Iscla, A. and Aleixandre, R. (2003) Los problemas del lenguaje técnico en la literatura médica actual. El Médico Interactivo. Diario Electrónico de la Sanidad (Valencia) no 892-10. http://www.medynet.com/elmedico/informes/informe/lenguaje.htm.

Kachru B. (1995) World Englishes: Approaches, issues, and resources. In: Readings on second language acquisition (Brown HD, Gonzo S, eds) Englewood Cliffs, NJ: PrenticeHall, pp 229-261.

Martínez Ramos, D. (2006) El lenguaje científico en cirugía. Una asignatura pendiente. Cirugía española. Vol. 79, $\mathrm{n}^{\circ} 02$ p. 83-88.

Mayor Serrano, $\mathrm{M}^{\mathrm{a}}$ B. (2006) Periodistas y traductores médicos: ¿dos mundos diferentes? Panacea Vol. VII, ${ }^{\circ} 23$.

Navarro, F.A. \& Hernández, F. (1992) Palabras de traducción engañosa en el inglés médico. Medicina Clínica Barcelona. Vol.99 p. 575-580.

Navarro, F.A. (1993) El nuevo Diccionario de la Real Academia Española: su repercusión sobre el lenguaje médico. Medicina Clínica Barcelona. Vol. 101, p. 584-590.

Navarro, F.A. \& Hernández, F. (1994) Nuevo listado de palabras de traducción engañosa en el inglés médico. Medicina Clínica Barcelona. Vol.102, p. 142-149.

Navarro F.A. (2001) La traducción médica ante el siglo XXI: tres retos para el lenguaje científico en español. Congreso internacional de la lengua española. Valladolid: RAE e Instituto Cervantes.

Navarro F.A (2000) Diccionario Crítico De Dudas Inglés-Español De Medicina. Madrid: Ed. McGraw-Hill

Navarro, F.A. (2005) Diccionario Crítico de dudas inglés-español de medicina $2^{\mathrm{a}}$ edición. MC. Graw-Hill.interamericana. Madrid.

Petzold, R. \& Berns, M. (2000). Catching up with Europe: Speakers and functions of English in Hungary. World Englishes, 19 (1), 113-124.

Rodríguez González, F. (1997) Nuevo diccionario de anglicismos. Madrid: Gredos.

Ruiz Garrido, M. (2003): Aplicaciones pedagógicas del informe empresarial en el aula del inglés de los negocios: implementación de recursos discursivos escritos en contextos de especialidad. Castellón: Universidad Jaime I. 